\title{
CLINICAL AND MICROBIOLOGICAL CHARACTERISTICS OF DIABETIC FOOT INFECTION BY CARBAPENEM-RESISTANT BACTERIA IN A HOSPITAL IN SOUTHERN BRAZIL
}

\section{Perfil clínico e microbiológico da infecção no pé diabético por bactérias carbapenêmico- resistentes em um hospital do sul do Brasil}

https://doi.org/10.18593/eba.27178

Recebido em 9 de janeiro de 2021. Aceito em 31 de maio de 2021.

\section{Stela Karine Braun*@@ Márcia Susana Nunes Silvat迎}

Mestre em Genética e Toxicologia aplicada pela Universidade Luterana do Brasil; doutoranda em Ciências Biológicas (Bioquímica Toxicológica) pela Universidade Federal de Santa Maria; Professora na Universidade Franciscana; Rua dos Andradas, 1614, Centro, 97010030, Santa Maria, Rio Grande do Sul, Brasil.

Doutora em Ciências Biológicas pela Universidade Federal do Rio Grande do Sul; Mestre em Microbiologia Agrícola e do Ambiente pela Universidade Federal do Rio Grande do Sul; Professora na Universidade Luterana do Brasil de Canoas.

Abstract: Carbapenem-resistant bacteria are a major cause of diabetic foot (DF) infection. They are resistant to almost all available antimicrobial agents and lead to increased hospital costs. The clinical and microbiological characteristics of DF infection due to these microorganisms and the association of DF with outcomes such as mortality and amputation are not yet well established. This was a retrospective cohort study involving 6o vascular surgery patients who were admitted to Nossa Senhora da Conceição Hospital due to DF infection caused by carbapenem-resistant bacteria and who underwent debridement or amputation, and a control group with 6o randomly selected patients. The analyzed parameters were mortality and amputation rates and patients' epidemiological and microbiological profiles. A significant association was observed between bacterial resistance and previous amputation, previous hospitalizations, and DF ulcer classification into ischemic and neuroischemic; however, there were no differences in mortality and amputation rates between the groups, even after using the Charlson comorbidity index. Although DF infections by carbapenem-resistant bacteria were not statistically associated with worse outcomes, their study is important given that there are few therapeutic options for treating these specific infections.

Keywords: antibiotic bacterial resistance; carbapenems; diabetic foot.

Resumo: As bactérias carbapenêmico-resistentes são uma causa importante de infecção no pé diabético (PD). Elas são resistentes à maioria dos agentes antimicrobianos disponíveis e estão associadas com aumento dos custos hospitalares. O perfil clínico e microbiológico da infecção no PD por esses microorganismos e a associação do PD com desfechos como mortalidade e amputação não são bem estabelecidos. Foi realizado um estudo de coorte retrospectiva envolvendo 6 o pacientes internados na cirugia vascular do Hospital Nossa Senhora da Conceição devido a infecção do PD por bactérias carbapenêmico-resistentes e que foram submetidos a amputação ou desbridamento e um grupo controle de 60 pacientes randomicamente selecionados. Foram analisados o perfil epidemiológico e microbiológico desses pacientes bem como as taxas de mortalidade e amputação. Observou-se uma associação significante entre resistência bacteriana e amputação prévia, hospitalização prévia e classificação do PD em isquêmico e neuro-isquêmico. No entanto, não houve diferença nas taxas de mortalidade e de amputação entre os grupos, mesmo com o uso do escore de comorbidades de Charlson. Apesar das infecções no PD por bactérias carbapenêmico-resistentes não serem associadas estatisticamente com piores desfechos, seu estudo é importante em função das poucas opções terapêuticas disponíveis para tratar essas infecções.

Palavras-chave: resistência bacteriana; carbapenêmicos; pé diabético. 


\section{INTRODUCTION}

Diabetic foot (DF) is used to describe the changes and complications that occur either alone or in combination in the feet and legs of diabetic patients. ${ }^{1}$ DF involves deep-tissue infection, ulceration, or necrosis associated with neurological abnormalities and various degrees of peripheral artery disease. ${ }^{2}$ DF is one of the most feared complications of diabetes and is a frequent cause of hospitalization, which is markedly associated with morbidity and mortality. The treatment of lesions is lengthy with a considerable rate of amputation. ${ }^{3}$

The profiles of these lower-limb lesions make them highly susceptible to acquisition, growth, and dissemination of antibiotic-resistant organisms due to their chronification potential, repeated use of antibiotics, and frequent visits to hospitals and healthcare facilities. ${ }^{2}$

Carbapenem-resistant bacteria are an important group among DF infection-causing bacteria. The fact that these microorganisms have different mechanisms of resistance is a significant challenge to health institutions because these pathogens are resistant to almost all available antimicrobial agents, which leads to high morbidity and mortality rates. ${ }^{4-9}$ The clinical and microbiological characteristics of DF infection by carbapenem-resistant bacteria and its association with outcomes such as mortality and amputation are not yet well established, which warrants the study of this topic.

\section{METHODS}

This was a retrospective cohort study involving vascular surgery patients admitted to the Nossa Senhora da Conceição Hospital (HNSC) due to DF infection caused by carbapenemresistant bacteria.

Patients who required surgical treatment (debridement or amputation) in 2013 due to infection by these bacteria were identified and monitored for at least 1 year to determine the rates of mortality and amputation; number of hospitalizations; epidemiological, clinical, and microbiological characteristics; and previous use of antibiotic therapy.

A total of 71 patients had cultures positive for carbapenem-resistant bacteria. Of these, 11 were excluded because they did not have type2 diabetes mellitus. Finally, 6o patients were included. The same outcomes were evaluated in all 60 diabetic patients with foot infections caused by the same carbapenem-sensitive bacteria, with the control group being randomly selected.

The sample used in this study comprised all patients of the HSNC Vascular Surgery Department with DF infection caused by carbapenem-resistant bacteria identified in the cultures of tissues debrided or amputated in 2013.

After approval from the Lutheran University of Brazil (ULBRA) Research Ethics Committee (Certificate of Presentation for Ethical Evaluation no. 37036614.7.00oo.5349), the project was submitted to the Brazilian National Council of Ethics in Research using the Plataforma Brasil online system and approved through the same system before the research was started. The information was obtained from discharge summaries and the in-hospital and outpatient clinical-course data present in the electronic medical records. The data were collected using a data collection form designed by the authors. Because of the retrospective nature of the study, 
a waiver for informed consent was granted by the institutional review board, and informed consent was not obtained before inclusion of the participants in the study.

The analyzed outcomes were hospital mortality, post-hospitalization mortality, and amputation rate. Hospital mortality was defined as deaths occurring during the hospitalization period, when the diagnosis was made via culture-based detection of bacterial resistance or sensitivity. Post-hospitalization mortality was defined as deaths occurring after this period. In addition, the bacterial cultures were reviewed and microbiological characteristics of the infections were determined.

Comorbidities are strong outcome predictors as well as are confounders. Therefore, based on the collected data, the Charlson comorbidity index and age-adjusted Charlson comorbidity index were calculated for each patient. This is a method for the classification of severity that uses data of secondary diagnoses to predict the risk of a patient's death. It is calculated as the sum of scores assigned to each condition and age. Higher scores indicate higher 10-year mortality risk.

\subsection{INCLUSION AND EXCLUSION CRITERIA FOR THE PATIENT GROUP}

The inclusion criteria were as follows: patients $>18$ years, with diabetes mellitus, and with a culture of debrided or amputated tissue performed in 2013 showing only resistance to carbapenems. The exclusion criteria were as follows: patients without diabetes mellitus, with a culture showing any resistant bacterium before or after $\mathbf{2 0 1 3}$, or a swab culture with bacteria resistant to any group of antibiotics.

\subsection{INCLUSION AND EXCLUSION CRITERIA FOR THE CONTROL GROUP}

The inclusion criteria were as follows: randomly selected individuals $>18$ years, with diabetes mellitus, with a culture of debrided or amputated tissue performed in 2013 in which carbapenem-sensitive enterobacteria or Pseudomonas aeruginosa were identified. The exclusion criteria were as follows: individuals without diabetes mellitus or with cultures performed in, before, or after 2013 in which any resistant bacterium was detected.

\subsection{STATISTICAL ANALYSIS}

The results were analyzed using descriptive analysis and non-parametric tests to evaluate the association with the investigated categorical variables. Chi-squared test was used when the assumptions were met for such cases; otherwise, Fisher's exact test was used for the pertinent variables. Student's t-test for age was used to assess significant differences between the patient and control groups with regard to the numerical variables, given that age distribution was found to be normal. Mann-Whitney's test was used to assess the association with the remaining variables because their distribution was not normal. The data were electronically processed and analyzed with the creation of a database (Excel ${ }^{\circledR}$ 2007) and using Statistical Package for Social Sciences, version 15.0 .

\section{RESULTS}

Our study sample comprised 120 patients; 6o in thegroup of infectionscaused bycarbapenemresistant bacteria and 60 in the control group. The mean age of patients was 64.33 and 63.30 years in 
the patient and control groups, respectively. No significant difference was observed in age between the groups. Most individuals were men in both groups, with $68.3 \%$ (41 patients) in the patient group and $70 \%$ (42 patients) in the control group.

Some clinical and microbiological characteristics are described in Table 1. Bacterial resistance was more prevalent among patients with ischemic or neuroischemic DF ( $p=0.008)$, those who had been previously amputated ( $\mathrm{p}=0.028)$, and those previously hospitalized $(\mathrm{p}=0.024)$. Further, there was no statistically significant difference between the groups with regard to previous antibiotic therapy $(p=0.070)$.

There was a predominance of enterobacteria in the carbapenem resistance group ( $85.5 \%)$, whereas this percentage was $65.2 \%$ in the control group $(\mathrm{p}=0.013)$. Coinfection with two resistant bacteria occurred in four cases in the patient group, whereas in the control group coinfection with two bacteria of the same profile but sensitive to carbapenems occurred in nine cases. Morganella morganii morganii was the most frequently detected resistant bacterial species, accounting for $\mathbf{4 2 . 2} \%$ of infections. In contrast, in the control group, the most common species was Pseudomonas aeruginosa, accounting for $34.8 \%$ of infections.

The outcomes analyzed in our study were mortality and amputation rates, and no significant difference was observed between the groups in either of them (Table 2). However, there was a statistically non-significant difference in hospital mortality and amputation rate, with higher values obtained in the group of patients with infection caused by carbapenem-resistant bacteria, which may be of clinical importance.

Table 1 - Clinical and microbiological characteristics of the carbapenem-resistant bacterial infection and control groups

\begin{tabular}{|c|c|c|c|}
\hline Variables & Groups & & P-value \\
\hline & Cases N (\%) & Control N (\%) & \\
\hline Diabetic foot & & & 0.008 \\
\hline Neuropathic & $19(31.7)$ & $34(56.7)$ & \\
\hline Ischemic & $30(50)$ & $23(38.3)$ & \\
\hline Neuroischemic & $11(18.3)$ & $3(5)$ & \\
\hline Previous hospitalizations & & & 0.024 \\
\hline Yes & $43(71.7)$ & $31(51.7)$ & \\
\hline No & $17(28.3)$ & $29(48.3)$ & \\
\hline Previous amputation & & & 0.028 \\
\hline Yes & $35(58.3)$ & $23(38.3)$ & \\
\hline No & $25(41.7)$ & $37(61.7)$ & \\
\hline Previous use of antibiotics & & & 0.07 \\
\hline Yes & $21(35.0)$ & $30(50)$ & \\
\hline No & $39(65.0)$ & $30(50)$ & \\
\hline Group of bacteria (co-infections included) & & & $0.013^{* *}$ \\
\hline Enterobacteria & $53(85 \cdot 5)^{*}$ & $45(65.2)$ & \\
\hline Pseudomonas & $9(14 \cdot 5)^{*}$ & $24(34.8)$ & \\
\hline
\end{tabular}

Note: *Two cases of carbapenem-resistant Acinetobacter are included. ** Fisher's exact test 
Table 2 - Analysis of outcomes in the groups of carbapenem-resistant and carbapenem-sensitive bacterial infections

\begin{tabular}{|c|c|c|c|}
\hline Variables & Groups & & P-value \\
\hline & $\begin{array}{c}\text { Cases N } \\
(\%)\end{array}$ & $\begin{array}{c}\text { Control } \\
\text { N (\%) } \\
\end{array}$ & \\
\hline Hospital mortality & & & $0.390^{*}$ \\
\hline Yes & $3(5)$ & $1(1.7)$ & \\
\hline No & $57(95)$ & $59(98.3)$ & \\
\hline Post-hospitalization mortality & & & 1 \\
\hline Yes & $6(10)$ & $6(10)$ & \\
\hline No & $54(90)$ & $54(90)$ & \\
\hline Total mortality (Hospital + Post-hospitalization) & & & $0.591^{*}$ \\
\hline Yes & $9(15)$ & $7(11.7)$ & \\
\hline No & $51(85)$ & $53(88.3)$ & \\
\hline Amputation & & & 0.841 \\
\hline Yes & $42(70)$ & $43(71.7)$ & \\
\hline No & $18(30)$ & $17(28.3)$ & \\
\hline Upper amputation & & & 0.323 \\
\hline Yes & $17(40.5)$ & $13(30.2)$ & \\
\hline No & $25(59 \cdot 5)$ & $30(69.8)$ & \\
\hline
\end{tabular}

Note: *Fisher's exact test.

The outcomes were analyzed for each group of bacteria (enterobacteria and Pseudomonas) and no difference was observed between the groups. Considering the enterobacteria group, there was no difference in hospital mortality $(\mathrm{p}=0.379)$ and total mortality ( $\mathrm{p}=0.362$ ) between the groups. Moreover, there was no difference in the rates of amputation $(\mathrm{p}=0.522)$ and major amputation ( $p=0.400$ ). Considering the Pseudomonas group, there were no deaths during hospitalization in any of the groups. In addition, there was no difference in total mortality ( $\mathrm{p}=0.095)$, amputation $(\mathrm{p}=0.400)$, and upper amputation $(\mathrm{p}=0.510)$ rates between the groups.

Because there was no significant difference in gross mortality rates between the groups, the Charlson comorbidity index was used to assess the association between the patients' comorbidities and risk of death. It was not possible to calculate other prognostic scores such as APACHE and SOFA because of the retrospective nature of the study and the unavailability of some data in the electronic records.

The Charlson comorbidity index and the age-adjusted Charlson comorbidity index were analyzed with regard to the variables mortality, amputation, and major amputation; and no differences were noted in mortality or amputation rates between the groups.

Table 3 shows the nonadjusted and ageadjusted Charlson scores with regard to the outcome death. In the patient group, there was a significant difference in the nonadjusted and ageadjusted Charlson indices between patients who died and those who survived, i.e., the patients who died had a higher score in both indices. In the control group, there was a significant difference only in the age-adjusted Charlson score, with a 
higher mean obtained among patients who died.

This difference in scores between patients who lived and those who died suggests that mortality is associated more with the severity of the patient's condition than with bacterial resistance to carbapenems.

Table 3 - Relationship between comorbidity scores and the outcome death

\begin{tabular}{|c|c|c|c|c|c|c|c|}
\hline Variable & Death & $\mathbf{N}$ & Mean & $\begin{array}{l}\text { Standard } \\
\text { deviation }\end{array}$ & Minimum & Maximum & p-value \\
\hline \multicolumn{8}{|c|}{ Carbapenem-resistant infection case group } \\
\hline \multirow[t]{2}{*}{ Charlson comorbidity index } & No & 51 & 2.8 & 1.2 & 2 & 6 & $0.002 a$ \\
\hline & Yes & 9 & 4.78 & 2.17 & 2 & 9 & \\
\hline \multirow[t]{2}{*}{$\begin{array}{l}\text { Age-adjusted Charlson comorbidity } \\
\text { index }\end{array}$} & No & 51 & 4.8 & 1.68 & 2 & 9 & $0.008 \mathrm{a}$ \\
\hline & Yes & 9 & 6.89 & 2.37 & 5 & 12 & \\
\hline \multicolumn{8}{|l|}{ Control group } \\
\hline \multirow[t]{2}{*}{ Charlson comorbidity index } & No & 53 & 2.77 & 1.37 & 2 & 9 & o.o8oa \\
\hline & Yes & 7 & 4.43 & 2.88 & 2 & 10 & \\
\hline \multirow[t]{2}{*}{$\begin{array}{l}\text { Age-adjusted Charlson comorbidity } \\
\text { index }\end{array}$} & No & 53 & 4.64 & 1.86 & 2 & 13 & $0.043 a$ \\
\hline & Yes & 7 & 6.43 & 2.51 & 4 & 11 & \\
\hline
\end{tabular}

Note: ${ }^{a}$ Mann-Whitney's test.

\section{DISCUSSION}

There are various factors associated with the increase in the rate of resistance, and they are classified into two categories: inappropriate use of antimicrobial agents and failure in hospital hygiene that favor cross-infection. However, there are few data on the risk factors involved in the colonization and infection of DF lesions. ${ }^{10}$

Our study sample comprised mostly of elderly male patients with poorly controlled diabetes mellitus, which demonstrates the complications that arise from the chronic nature of diabetes mellitus and the importance of adequate glycemic control. The factors associated with DF infection by carbapenem-resistant bacteria were the classification of DF into ischemic or neuroischemic and a history of amputation and hospitalization. The etiology of the lesions in the total sample (120 patients with DF infections) was neuropathic $(44 \%)$, ischemic $(44 \%)$, or neuroischemic (12\%). A study with 180 patients with DF was conducted and the authors ${ }^{10}$ reported that the DF lesions were ischemic or neuroischemic in $63 \%$ patients and neuropathic in $37 \%$ of the sample. Ischemic wounds are characterized by complications in micro and macrocirculation, which lead to low penetration of antibiotics in the lower limbs tissues and longer exposure to them, which in turn can induce bacterial resistance. They also showed that the type of ulcer (ischemic) was an independent risk factor for DF infection caused by multiresistant organisms."

The relationship between previous amputation and bacterial resistance may be explained by frequent contact with healthcare 
services, previous hospitalizations, and previous use of antimicrobial agents. In another study, ${ }^{2}$ $32 \%$ patients had already undergone amputation. Those subjected to above-knee amputations had an increased risk of subsequent contralateral amputation. In our study, almost 6o\% patients in the patient group had undergone amputation.

Previous use of antibiotics was not significantly associated with bacterial resistance in our study. An association between previous use of antibiotic therapy and bacterial resistance has been reported. There is a significant association between previous antibiotic therapy and infection by a resistant microorganism. ${ }^{12}$ Other authors ${ }^{11}$ also stated that the prolonged use of broad-spectrum antibiotics increases the risk of emergence of multiresistant organisms. A limitation of our study was the fact that this information was not always documented because there were no data on the use of antibiotics before the studied hospitalization period.

In our study, there was a significant association between previous hospitalizations and bacterial resistance, a finding that is in line with the literature. DF infections caused by multiresistant organisms were associated with a history of hospitalization, suggesting that the infections were acquired during hospitalization via cross-infection. ${ }^{2,10-12}$

We evaluated the data regarding bacterial cultures, and found a statistically significant dominance of enterobacteria in the patient group relative to the other groups of bacteria. The microbiological characteristics of DF infections have been described in several studies conducted in the last 25 years, but the results are varied and often contradictory. These discrepancies may be due to differences in the causative organisms, which change with time, geography, and infection type, and severity. ${ }^{13}$ Previous use of antibiotic therapy and the selected method of sample collection and analysis also influence the diversity of pathogens in DF among different institutions. ${ }^{14}$ A study ${ }^{15}$ reported a predominance of Gram-negative bacteria in DF infections, with a considerable percentage of Morganella morganii. These authors related a lack of education and hygiene in their study group with the presence of these bacteria. The conditions of patients in our study were similar to those of patients in that study, conducted in the Brazilian state of Ceará. Another research ${ }^{16}$ also reported a considerable amount of infections by Morganella. This finding may also be related with poor hand hygiene, use of broad-spectrum antimicrobial agents, and to poor local physical conditions. It was also reported by other authors ${ }^{17}$ that Gram-negative bacteria were more common isolates in DF infections, similarly to many studies conducted in India.

Several studies have investigated whether resistance to carbapenems is associated with increased mortality. ${ }^{6,7,9,10,18,19}$ This association was not observed in our study, which is in line with several reports that deny this association. In addition, there was a considerable rate of mortality in the patient and control groups because the majority of patients were older individuals with a high Charlson score and with various comorbidities who experienced an infectious episode during hospitalization.

The differences in mortality may be due to organism-, patient-, and treatment-related factors. As with other infections caused by antibiotic-resistant pathogens, patients with carbapenem-resistant Enterobacteriaceae tend to exhibit greater disease severity and more comorbid 
conditions than those with infections caused by carbapenem-susceptible Enterobacteriaceae. ${ }^{19}$

Multiresistant organisms have a deleterious effect on the outcome of severe acute infections such as bacteremia or pneumonia, but not on chronic diseases like DF, for which active antimicrobial agents are available. ${ }^{10}$

The effect of antibiotic resistance on the outcomes of patients with nosocomial infections is controversial. Despite the acceptance of the idea that bacterial resistance is associated with increased morbidity and mortality, several authors did not observe this relationship. Comorbidities, delays in starting appropriate antibiotic therapy, and disease severity in patients infected by multiresistant pathogens may be important confounding factors. Appropriate adjustment of these confounding factors is essential in studies that determine the effect of antimicrobial resistance. ${ }^{18}$

In our study, there was no difference in the amputation rate between the groups. With regard to major amputation, the group of resistant infections had four more amputations than the control group, but the difference was not statistically significant. As there was no statistically significant difference in gross mortality or amputation rates between the groups, both the nonadjusted and age-adjusted Charlson comorbidity indices were used to assess the effect of previous diseases on the patients' outcomes. However, no significant differences were observed in these indices between the groups. The analysis of the outcomes (mortality and amputation rates) and of the two Charlson comorbidity indices in the groups showed no significant differences. The Charlson scores were higher in patients who died than in those who survived, i.e., the patients who died had more associated conditions that were probably the causes of death.
The main limitation of this study is its observational and retrospective nature, with difficulties in data retrieval from medical records. In addition, this was a single-center study and the results cannot be generalized to other centers.

\section{CONCLUSION}

Although DF infections by carbapenemresistant bacteria were not statistically associated with worse outcomes, their study is important, especially regarding preventive measures that avoid their occurrence, given that there are few options for the treatment of these infections. To date, there is no study on DF infections by carbapenem-resistant bacteria. Therefore, further studies on this topic are required to confirm the findings of our study.

\section{ACKNOWLEDGMENTS}

The authors would like to thank their colleagues from the Nossa Senhora da Conceição Hospital; they would also like to thank Crimson Interactive Pvt. Ltd. (Ulatus) - www.ulatus.com.br - for their assistance in manuscript translation and editing

\section{DISCLOSURES}

The authors don't have any conflict of interest

\section{FUNDING}

This research did not receive any specific grant from funding agencies in the public, commercial, or not-for-profit sectors. 


\section{REFERENCES}

1. Caiafa JS, Castro AA, Fidelis C, Santos VP, Silva ES, Sitrangulo CJ. Atenção integral ao portador de pé diabético. J Vasc Bras. 2011;10: 1-32.

2. Quilici MTV. Uso prévio de antimicrobianos em pacientes hospitalizados com pé diabético [dissertação]. Sorocaba: Universidade de Sorocaba; 2011.

3. Brasileiro JL, Oliveira WTP, Monteiro LB, Chen J, Pinho EL, Molkenthin S, et al. Pé diabético: aspectos clínicos. J Vasc Bras. 2005;4: 11-21.

4. Vinodkumar CS, Hiresave S, Giriyapal BK, Bandekar N. Metallo beta lactamase producing Pseudomonas aeruginosa and its association with diabetic foot. Indian J Surg. 2011;73: 291-4.

5. Zubair M, Malik A, Ahmad J. Prevalence of metallo-beta-lactamase-producing Pseudomonas aeruginosa isolated from diabetic foot ulcer patients. Diabetes Metab Syndr: Clinical Research \& Reviews. 2011;5: 90-2.

6. Echeverri-Toro LM, Rueda ZV, Maya W, Agudelo Y, Ospina S. Klebsiella pneumoniae multi-resistente, factores predisponentes y mortalidad asociada en un hospital universitário en Colombia. Rev Chil Infectol. 2012;29: 175-82.

7. Correa L, Martino MDV, Siqueira I, Pasternak J, Gales AC, Silva CV, et al. A hospital-based matched case-control study to identify clinical outcome and risk factors associated with carbapenem-resistant Klebsiella pneumoniae infection. BMC Infect Dis. 2013;13: 1-8.

8. Queiroz GM, Da Silva LM, Pietro RCLR, Salgado HRN. Multirresistência microbiana e opções terapêuticas disponíveis. Rev Soc Bras Clin Med. 2012;10: 132-8.

9. Lemos EV, De La Hoz FP, Einarson TR, McGhan WF, Quevedo E, Castañeda C, et al. Carbapenem resistance and mortality in patients with Acinetobacter baumanni iinfection: systematic review and meta-analysis. Clin Microbiol Infect. 2014;20: 416-23.

10. Hartemann-Heurtier A, Robert J, Jacqueminet S, Ha Van G, Golmard JL, Jarlier V. Diabetic foot ulcer and multidrug-resistant organisms: risk factors and impact. Diabet Med. 2004;21: 710-5.

11. Ji X, Jin P, Chu Y, Feng S, Wang P. Clinical characteristics and risk factors of diabetic foot ulcer with multidrug-resistant organism infection. Int J Lower Extrem Wounds. 2014;13: 64-71.

12. Kandemir Ö, Akbay E, Sahin E, Milcan A, Gen R. Risk factors for infection of the diabetic foot with multi-antibiotic resistant microorganisms. J Infect. 2007;54: 439-45. 
13. Priyadarshini S, Jeya M, Linda SS. The bacteriology of diabetic foot ulcers, with a special reference to multidrug resistant strains. J Clin Diagn Res. 2013;7: 441-5.

14. Uçkay I, Gariani K, Pataky Z, Lipsky BA. Diabetic foot infections: state-of-the-art. Diabetes Obes Metab. 2014;16: 305-16.

15. Neto RM, De Carvalho CBM, Mota MO, Saldanha GB, Abreu CVMP. Pé diabético: etiologia e resistência a antimicrobianos de cepas isoladas em moradores do estado do Ceará. NewsLab. 2004;65: 118-30.

16. Aragão ML, Fernandes VO, Quidute ARP, Sales APAM, Dantas FCM, Porto LB. Perfil microbiológico e desfechos clínicos de úlceras graves em pés. Rev Bras Promoç Saúde. 2010;23: 231-6.

17. Saseedhran S, Sahu M, Chaddha R, Pathrose E, Bal A, Bhalekar P, et al. Epidemiology of diabetic foot infection in a reference tertiary hospital in India. Braz J Microbiol. 2018;49: 401-6.

18. Ben-David D, Kordevani R, Keller N, Tal I, Marzel A, Gal-Mor O, et al. Outcome of carbapenem resistant Klebsiella pneumoniae bloodstream infections. Clin Microbiol Infect. 2012;18: 54-6o.

19. Martin A, Fahback K, Zhaq Q, Lodise T. Association between carbapenem resistance and mortality among adult, hospitalized patients with serious infections due to Enterobacteriaceae: results of a systematic literature review and meta-analysis. Open Forum Infect Dis. 2018;5: 1-9. 